\title{
Multipurpose Acoustic Networks in the Integrated Arctic Ocean Observing System
}

\author{
Peter N. Mikhalevsky, ${ }^{1}$ Hanne Sagen, ${ }^{2}$ Peter F. Worcester, ${ }^{3}$ Arthur B. Baggeroer, ${ }^{4}$ John Orcutt, ${ }^{3}$ Sue E. Moore, ${ }^{5}$ \\ Craig M. Lee, ${ }^{6}$ Kathleen J. Vigness-Raposa, ${ }^{7}$ Lee Freitag, ${ }^{8}$ Matthew Arrott, ${ }^{3}$ Kuvvet Atakan, ${ }^{9}$ \\ Agnieszka Beszczynska-Möller, ${ }^{10}$ Timothy F. Duda, ${ }^{8}$ Brian D. Dushaw, ${ }^{6}$ Jean Claude Gascard, ${ }^{11}$ \\ Alexander N. Gavrilov, ${ }^{12}$ Henk Keers, ${ }^{9}$ Andrey K. Morozov, ${ }^{13}$ Walter H. Munk, ${ }^{3}$ Michel Rixen,,${ }^{14}$ \\ Stein Sandven, ${ }^{2}$ Emmanuel Skarsoulis, ${ }_{15}^{15}$ Kathleen M. Stafford, ${ }^{6}$ Frank Vernon ${ }^{3}$ and Mo Yan Yuen ${ }^{9}$
}

(Received 26 May 2014; accepted in revised form 20 October 2014)

\begin{abstract}
The dramatic reduction of sea ice in the Arctic Ocean will increase human activities in the coming years. This activity will be driven by increased demand for energy and the marine resources of an Arctic Ocean accessible to ships. Oil and gas exploration, fisheries, mineral extraction, marine transportation, research and development, tourism, and search and rescue will increase the pressure on the vulnerable Arctic environment. Technologies that allow synoptic in situ observations year-round are needed to monitor and forecast changes in the Arctic atmosphere-ice-ocean system at daily, seasonal, annual, and decadal scales. These data can inform and enable both sustainable development and enforcement of international Arctic agreements and treaties, while protecting this critical environment. In this paper, we discuss multipurpose acoustic networks, including subsea cable components, in the Arctic. These networks provide communication, power, underwater and under-ice navigation, passive monitoring of ambient sound (ice, seismic, biologic, and anthropogenic), and acoustic remote sensing (tomography and thermometry), supporting and complementing data collection from platforms, moorings, and vehicles. We support the development and implementation of regional to basin-wide acoustic networks as an integral component of a multidisciplinary in situ Arctic Ocean observatory.
\end{abstract}

Key words: Arctic observing systems; Arctic acoustics; acoustic tomography; cabled networks; passive acoustics; active acoustics

RÉSUMÉ. La diminution remarquable de la glace de mer dans l'océan Arctique aura pour effet d'intensifier l'activité humaine dans cette région au cours des années à venir. Ces activités s'accompagneront d'une demande accrue en ressources marines et en énergie du fait que l'océan Arctique sera accessible aux bateaux. L'exploration pétrolière et gazière, la pêche, l'extraction minière, le transport maritime, la recherche et le développement, le tourisme et les activités de recherche et sauvetage mettront davantage de pression sur l'environnement vulnérable de l'Arctique. Il y a lieu de se doter de technologies qui permettront de faire des observations sur place à l'année afin de surveiller et de prévoir les changements caractérisant le système atmosphère-glace-océan de l'Arctique à l'échelle quotidienne, saisonnière, annuelle et décennale. Ces données seront utiles tant pour le développement durable que pour l'application des accords et traités internationaux relativement à l'Arctique, et elles permettront de protéger cet environnement critique. Dans cet article, nous discutons des réseaux acoustiques à vocations multiples de l'Arctique, notamment l'aspect des câbles sous-marins. Ces réseaux permettent les communications, le transport

${ }^{1}$ Corresponding author: Leidos, Inc., 4001 N. Fairfax Dr., Suite 725, Arlington, Virginia 22203, USA; mikhalevskyp@leidos.com

${ }^{2}$ Nansen Environmental and Remote Sensing Center, Thormøhlensgt 47, 5006 Bergen, Norway

${ }^{3}$ Scripps Institution of Oceanography, University of California, San Diego, 9500 Gilman Drive, 0225, La Jolla, California 920930225, USA

${ }^{4}$ Massachusetts Institute of Technology, Cambridge, Massachusetts 02139, USA

${ }^{5}$ National Oceanic and Atmospheric Administration/Fisheries Science and Technology-PMEL, 7600 Sand Point Way, Seattle, Washington 98115, USA

${ }^{6}$ Applied Physics Laboratory, University of Washington, Seattle, Washington 98105, USA

${ }^{7}$ Marine Acoustics, Inc., 809 Aquidneck Avenue, Middletown, Rhode Island 02842, USA

${ }^{8}$ Woods Hole Oceanographic Institution, 86 Water Street, Woods Hole, Massachusetts 02543 USA

${ }^{9}$ Department of Earth Science, University of Bergen, Allégt. 41, N-5007 Bergen, Norway

${ }^{10}$ Institute of Oceanology, Polish Academy of Sciences, Powst. Warszawy 55, 81-712 Sopot, Poland

${ }^{11}$ LOCEAN, Université Pierre et Marie Curie, 4 place Jussieu (Tour 45-46, 5e) 75005 Paris, France

${ }^{12}$ Centre for Marine Science and Technology, Curtin University of Technology, GPO Box U1987, Perth WA 6845, Australia

${ }^{13}$ Teledyne Web Research, 49 Edgerton Drive, North Falmouth, Massachusetts 02556, USA

${ }^{14}$ World Meteorological Organization, 7bis, Avenue de la Paix, Case postale 23000, CH-1211 Geneva 2, Switzerland

${ }^{15}$ Foundation for Research and Technology Hellas, Inst. of Applied and Computational Mathematics, PO Box1385, GR-71110 Heraklion, Greece

(C) The Arctic Institute of North America 
de l'énergie, la navigation sous-marine et sous les glaces, la surveillance passive du son ambiant (glace, bruits sismiques, biologiques et anthropiques), la détection acoustique à distance (tomographie et thermométrie) de même que le soutien et le complément aux données recueillies à partir des plateformes, des amarres et des véhicules. Nous sommes pour l'aménagement et l'utilisation de réseaux acoustiques régionaux à la grandeur du bassin comme composante intégrante d'un observatoire multidisciplinaire sur place dans l'océan Arctique.

Mots clés : systèmes d'observation dans l'Arctique; acoustique de l'Arctique; tomographie acoustique; réseaux câblés; acoustique passive; acoustique active

Traduit pour la revue Arctic par Nicole Giguère.

\section{INTRODUCTION}

The development and implementation of the infrastructure for multipurpose acoustic networks in the Arctic Ocean would support in situ ocean observations with instrumented moorings, autonomous vehicles, and floats, as well as with acoustics (Dushaw et al., 2010; Sagen et al., 2010). The OceanObs ${ }^{\circ} 09$ Conference Summary (Fischer et al., 2010) identifies active and passive ocean acoustics as a proven technology for in situ ocean observing. Selected moorings can be cabled to shore to provide both energy for high-power sensors (such as vertical profilers and acoustic sources) and high-speed, real-time, year-round communications to extract data from local sensors (broadband seismometers and hydrophones, autonomous vehicles, and floats), as well as from distant sensors that communicate acoustically. A fully cabled network with several landfalls can realistically provide the various component services needed for long-term climate change monitoring over many decades (the typical operational life of cabled systems). Acquiring and installing a cabled system can be as costly as acquiring a research ship; however, these costs are competitive when amortized over the multi-decade lifetime of the system. And cabled networks provide continuous, persistent real-time observations year-round, which are not possible with ships alone. Technologies for such a system exist, but international collaboration, coordination, and synchronization of funding for long-term infrastructure in the Arctic Ocean are required to implement a basin-wide network.

OceanObs'99 identified high-latitude regions and the Arctic Ocean as key areas where ocean acoustic tomography should be applied (Global Ocean Observing System Steering Committee, 2000; IOC, 2000; Dushaw et al., 2001). Stand-alone acoustic tomography and thermometry systems have been used successfully in ice-covered regions at high latitudes. The 1988-89 Greenland Sea Experiment (Worcester et al., 1993; Morawitz et al., 1996a, b) and the six-year Labrador Sea experiment (Avsic et al., 2005) successfully observed deep-water formation processes. In the High Arctic, the 1994 Transarctic Acoustic Propagation (TAP) experiment (Mikhalevsky et al., 1999) and the Arctic Climate Observations Using Underwater Sound (ACOUS) experiment in 1998-99 (Mikhalevsky et al., 2001) observed basin-scale warming of the Arctic Intermediate Water (AIW).
Acoustic tomography and thermometry measure ocean temperatures and currents throughout the water column, including the abyssal zone, to determine the heat content and mean circulation on regional and basin scales using precise measurements of travel times between acoustic sources and receivers (thermometry refers to average temperature measurements in a two-dimensional vertical slice along a single path, and tomography refers to using multiple intersecting paths and tomographic inversion to provide a three-dimensional spatial temperature map). Through inversion techniques, internal ocean temperature can be retrieved with an accuracy of $0.01^{\circ} \mathrm{C}$ over a $200 \mathrm{~km}$ distance (Munk et al., 1995; Dushaw et al., 2010). Average current velocities are determined from the differences between reciprocal travel times produced by simultaneously transmitting acoustic pulses in opposite directions along an acoustic path. Because of the high accuracy and integral nature of the data, acoustic travel times can be used to validate and constrain numerical ocean circulation models by data assimilation (e.g., Munk et al., 1995; ATOC Consortium, 1998; Dushaw et al., 2009; Haugan et al., 2012). In the Arctic Ocean, with its upward refracting sound speed profile, the depth dependence of the acoustic modes increases monotonically with mode number. Higher modes sample greater depths. With the vertically stratified major water masses of the Arctic basin, acoustic modes can selectively sample specific water masses, such as the AIW (Mikhalevsky et al., 1999; Mikhalevsky, 2001) and the deep Arctic water.

The same tomography/thermometry network of acoustic sources and receivers can also provide long-term passive acoustic listening, underwater acoustic navigation (performing a global positioning system [GPS] function underwater), and low bandwidth communications providing the navigation and timing required for under-ice operation of autonomous gliders, floats, and unmanned undersea vehicles (UUVs) in the Arctic (Fig. 1). Gliders, floats, and UUVs obtain sea ice observations and oceanographic fields with high resolution in space, complementing the horizontally averaged, high temporal resolution acoustic measurements. The spatially synoptic, high temporal resolution observations provided by acoustic tomography offer the possibility of adaptive sampling of events as they develop by detecting events and then guiding mobile assets to the regions of interest. 


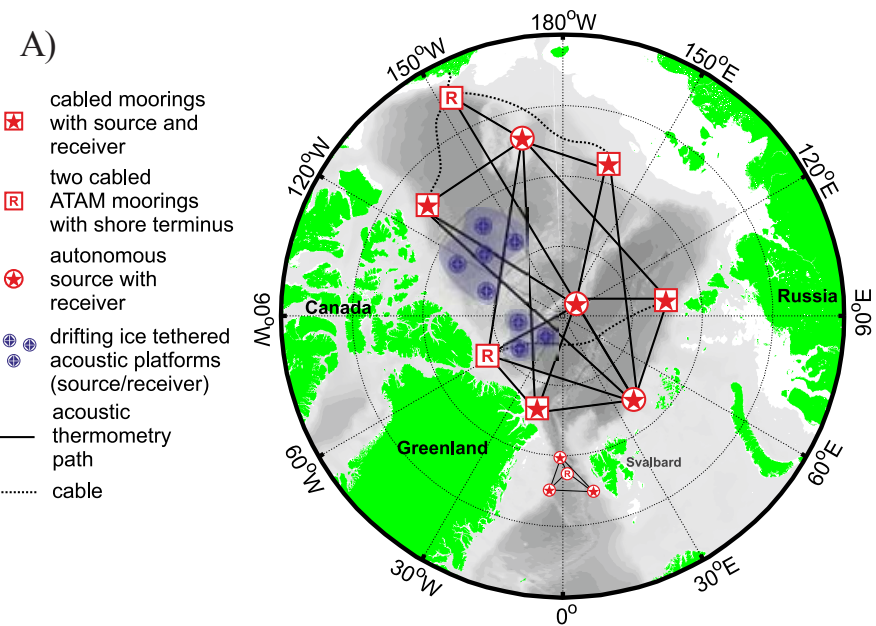

B)
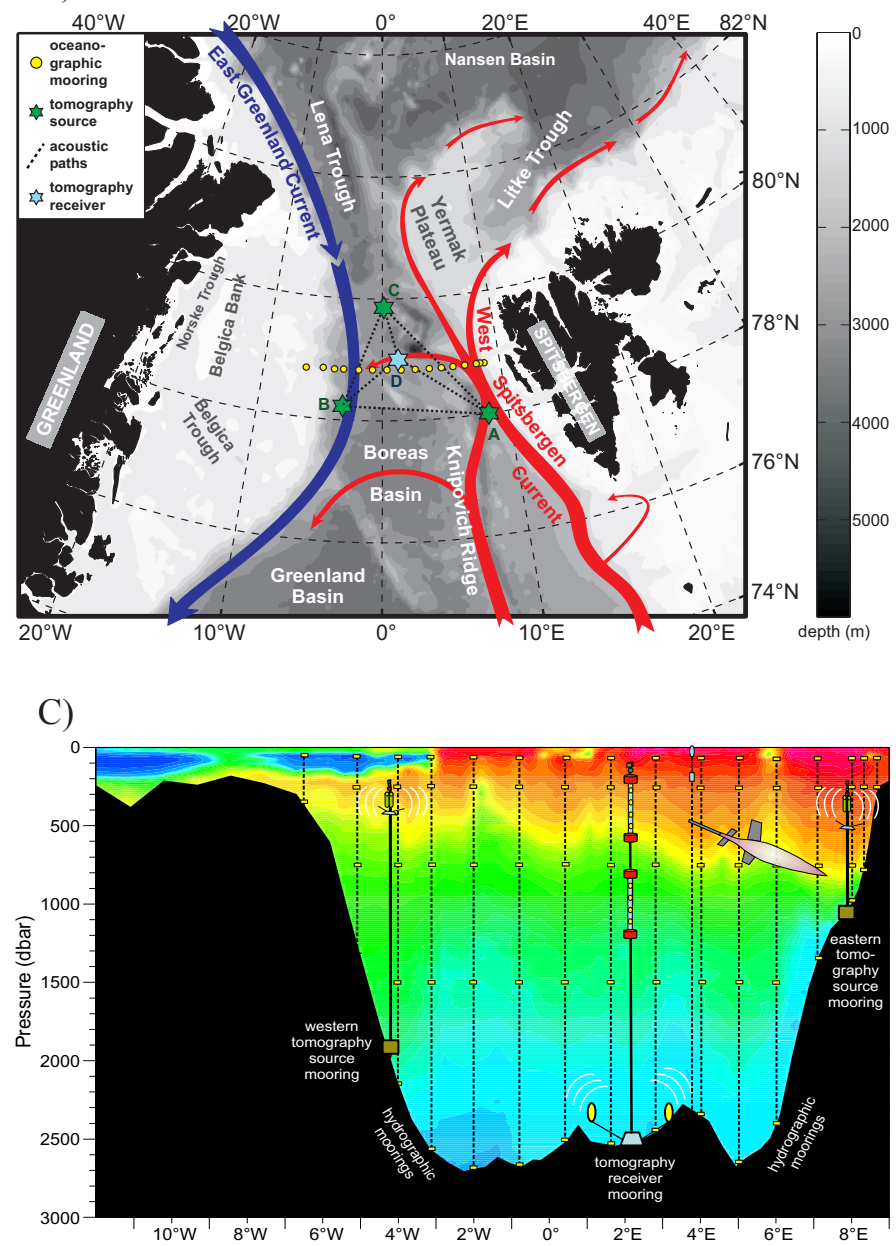

FIG. 1. A) The notional basin-wide Arctic mooring network for acoustic thermometry/tomography, oceanography, and underwater "GPS" system for navigation of and low rate communications with floats, gliders, and UUVs. ATAM is an Acoustic Thermometry and Multipurpose Mooring and applies to all the moorings shown. B) The Fram Strait multipurpose acoustic system deployed from 2010 to 2012 for tomography, positioning of gliders and floats, and passive acoustics (http://acobar.nersc.no). The system includes three transceiver moorings $(\mathrm{A}, \mathrm{B}, \mathrm{C})$ and a receiver mooring $(\mathrm{D})$. The array of oceanographic moorings across the strait at $78^{\circ} 50^{\prime} \mathrm{N}$ is shown by yellow dots. C) The vertical section shows the position of these moorings overlain on the temperature distribution in Fram Strait (red indicates warm Atlantic water and blue depicts cold Arctic waters). (Courtesy of the ACOBAR project, http://acobar.nersc.no.)
The in situ observations of the interior of the Arctic Ocean complement satellite remote sensing of sea ice and sea surface properties. Acoustic networks can improve observations of the water column beneath the ice directly, using tomographic/thermometry measurements, while simultaneously providing acoustic navigation and communications supporting autonomous vehicles. Such a system can be used to investigate processes affecting stratification and mixing of water masses and the impact of these processes on ice melting, for example. Because these networks sense ocean properties throughout the water column, both under ice and in open water, their in situ observations fill an important observational gap with data that are inaccessible by satellites.

Regional acoustic tomography/thermometry networks with acoustically supported autonomous vehicles can improve the observations of water mass exchanges between the Arctic and the world oceans through the major straits. The Fram Strait multipurpose acoustic network (Sagen et al., 2011; Sandven et al., 2013) (Fig. 1) described below is a working model of the application of acoustics for tomography, navigation, and communications.

\section{APPLICATIONS OF ACOUSTIC NETWORKS IN THE ARCTIC}

\section{Acoustic Thermometry and Tomography}

In recent decades, the Arctic Ocean has experienced dramatic changes, with record low sea ice extent in summer, including a new record minimum set in 2012 (NSIDC, 2012), and the significant reduction of multiyear ice (Maslanik et al., 2011; NRC, 2012). Atmospheric warming is a dominant force in the melting of ice, but melting by warming from underlying water masses is also possible. A $100-200 \mathrm{~m}$ thick surface layer of low-salinity, cold water protects the ice cover from more extensive melting by the warmer underlying water of Atlantic origin. It is well documented that the ice is becoming thinner and more seasonal (Wadhams, 2012), which will lead to stronger exposure of the surface layer to wind-induced mixing. In this case, the sea ice melt will accelerate beyond what we have seen so far. The accelerated melting observed recently might indicate that this process is already in progress. Climate models are not yet able to reproduce the observed acceleration in ice melting (Rampal et al., 2011) and could be improved with the integral constraints provided by in situ acoustic thermometry and tomographic data. To maintain the halocline layer, the weakness of the turbulent mixing of the water masses is crucial (Fer, 2009). Recent findings show that dynamic processes, such as large inertial waves, enhanced shear, and mixing, are closely related to the presence of sea ice (Rainville and Woodgate, 2009). A seasonally ice-free Arctic Ocean can become more like a marginal ice zone and lead to a redistribution of water masses, with a weakened isolating halocline layer. 

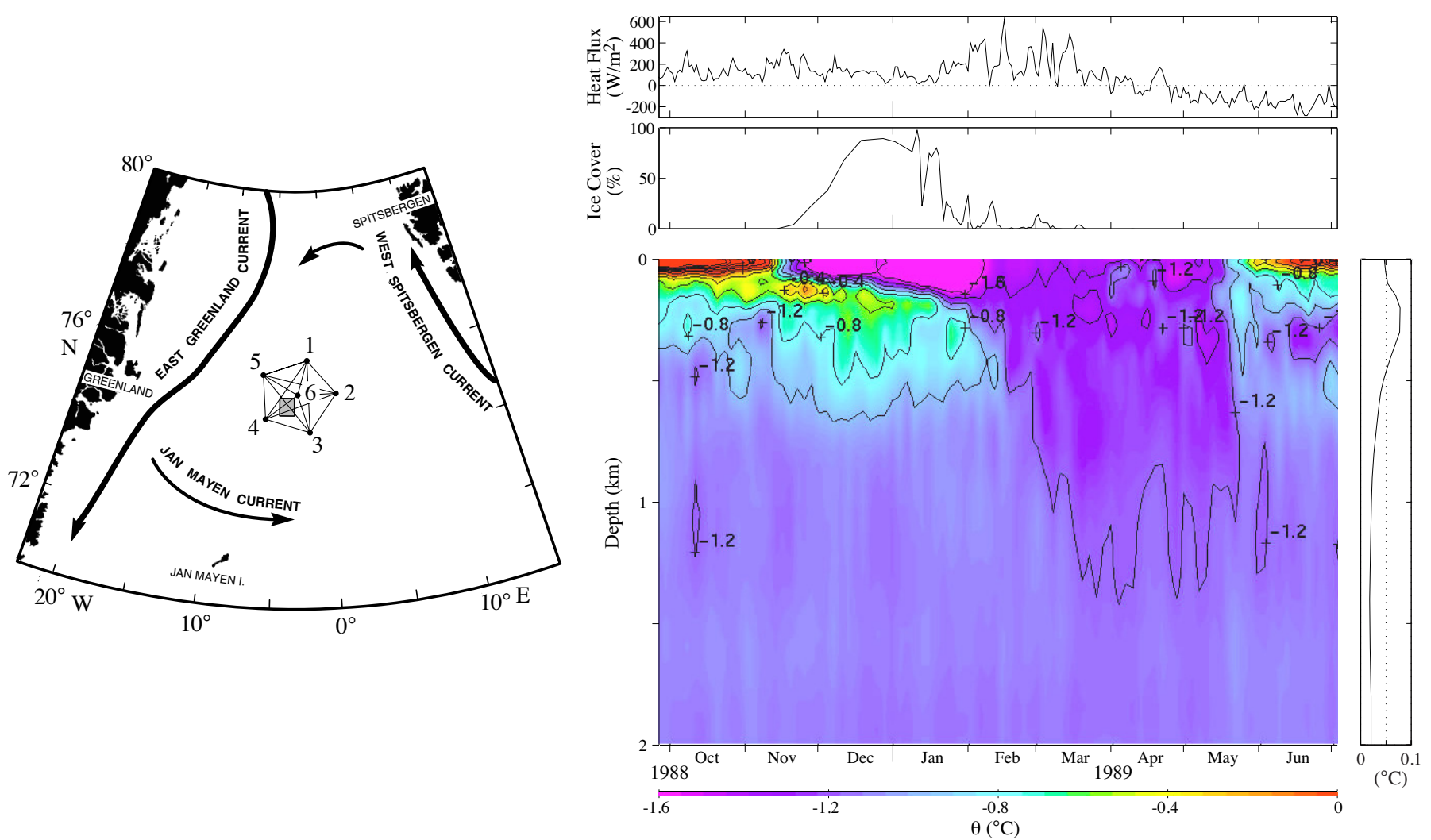

FIG. 2. Left: Geometry of the tomographic transceiver array deployed in the Greenland Sea during 1988-89. A deep convective chimney was observed near the center of the array during March 1989 (shaded region). Right: Time-depth evolution of potential temperature averaged over the chimney region. The contour interval is $0.2^{\circ} \mathrm{C}$. Typical rms uncertainty $\left({ }^{\circ} \mathrm{C}\right.$ ) as a function of depth is shown to the far right. Total heat flux (from the British Meteorological Office) and daily averaged ice cover (derived from satellite SSM/I measurements) are shown above. (Adapted from Morawitz et al., 1996a.)

In the Greenland Sea Experiment (Worcester et al., 1993; Morawitz et al., $1996 \mathrm{a}, \mathrm{b})$, the tomographic array observed the evolution and breakup of a deep convective chimney in March 1989 (Fig. 2). During the course of this one-year experiment, the average annual deep-water production rate was calculated from the tomographic temperature inversions to be $0.1 \mathrm{~Sv}$ over the region spanned by the array.

In the High Arctic, the successful trans-Arctic acoustic thermometry experiments demonstrated the unique capability of underwater acoustics to measure large-scale changes in temperature and heat content of the Arctic Ocean. In the 1994 TAP experiment, transmissions from a source located north of the Svalbard Archipelago to receivers in the Lincoln Sea (1000 km distant) and the Beaufort Sea $(2600 \mathrm{~km}$ distant) revealed, for the first time, basin-scale warming of the AIW (Mikhalevsky et al., 1999), which was then confirmed by submarine measurements (Mikhalevsky et al., 2001). In the ACOUS experiment in 1998-99, transmissions from a source deployed in Franz Victoria Strait to receivers in the Lincoln Sea and the Chukchi Sea measured continued basin-scale warming of the AIW and detected a rapid warming in a broadly dispersed mass of Atlantic water with a maximum temperature that exceeded $2.5^{\circ} \mathrm{C}$ crossing the Nansen Basin north of the Franz Victoria Strait in August-December 1999 (Mikhalevsky et al., 2001). This intrusion of warm Atlantic water was most likely the result of a wide frontal zone crossing the acoustic path, instead of a gradual spread of the warmer Atlantic water core from the continental slope to the central part of the basin (Gavrilov and Mikhalevsky, 2002). This analysis exploited knowledge of the climatology of the region and the spatially averaged, acoustic mode resolving thermometry that provided depth resolution. It would have been difficult to observe the warming without many conventional point moorings over the $400 \mathrm{~km}$ span of this water mass. Furthermore, had oceanographic gliders been available as envisioned with a multipurpose network, they could have been deployed across this water mass for more detailed spatial sampling as the event was occurring. This pulse of warm Atlantic water was observed on moorings in the Fram Strait, as reported by Beszczynska-Möller et al. (2012).

The ACOUS experiment also showed that the received acoustic energy was correlated with path-average ice thickness changes, which could provide means for continuous remote observation of basin-scale changes in the average Arctic sea ice thickness (Gavrilov and Mikhalevsky, 2006).

More recently, multipurpose acoustic networks have been installed in Fram Strait in the EU funded DAMOCLES (Developing Arctic Modeling and Observing Capabilities for Long-term Environmental Studies) and ACOBAR (ACoustic technology for OBserving the interior of the ARctic Ocean) projects for ocean acoustic tomography, positioning of gliders and floats, underwater communication, and passive acoustic monitoring, as discussed below. 
One of the key goals is to provide improved estimates of the fluxes of mass, heat, and freshwater through the Strait by assimilating the integral acoustic measurements, together with data from satellites, moorings, gliders, and floats, in high-resolution ocean models (e.g., Sandven et al., 2013).

\section{Underwater Acoustic Navigation and Communication}

Gliders and floats have become important platforms for oceanographic data collection. The ARGO program maintains an operational array of more than 3000 profiling floats, distributed over the ice-free oceans at nominal $300 \mathrm{~km}$ lateral spacing. The current generation of autonomous gliders operates routinely in lower-latitude oceans for periods of up to a year to provide persistent sampling in difficult conditions and remote areas, including strong boundary currents and harsh wintertime subpolar seas. These autonomous platforms rely on satellite-based geolocation (GPS) and telemetry (Iridium and ARGOS), but in the Arctic, ice cover can block access to the sea surface and thus prevent instruments from using these critical services (Lee and Gobat, 2006). High-frequency $(10 \mathrm{kHz})$ acoustic modems can provide sufficient bandwidth for underwater transfer of data and commands at modest ranges of several kilometres, but subsurface telemetry at longer ranges at high frequencies remains problematic, irrespective of ice cover. Recent implementations of mid-frequency $(200-1000 \mathrm{~Hz})$ acoustic positioning systems that rely on triangulation from an array of sound sources (e.g., RAFOS floats, Rossby et al., 1986; Ocean Instruments, 2015) provide regional-scale (hundreds of kilometres) geolocation in ice-covered waters. Previous studies (e.g., Gavrilov and Mikhalevsky, 2002, 2006) suggest that low-frequency $(10-100 \mathrm{~Hz})$ systems could provide basin-scale geolocation, underwater "GPS," in ice-covered environments, but such systems have not yet been implemented. New results of estimating the uncertainty in subsurface glider position using transmissions from fixed $200-300 \mathrm{~Hz}$ acoustic tomography sources at ranges up to $700 \mathrm{~km}$ in the Philippine Sea are very promising (Van Uffelen et al., 2013).

Development of the first regional-scale (hundreds of kilometres) system for operating gliders in ice-covered waters began in 2005, as part of a project supported by the U.S. National Science Foundation that focused on understanding Arctic-Subarctic exchange through Davis Strait. Davis Strait, one of the two primary pathways through which Arctic waters exit into the subpolar North Atlantic, provided a convenient site for development of ice-capable Seagliders at a location where the resulting measurements would greatly augment the existing observing system. Initial testing of $780 \mathrm{~Hz}$ RAFOS sources in Davis Strait, substantiated by the performance of the operational array, indicates effective navigation ranges of $100-150 \mathrm{~km}$ in ice-covered waters. Surface ducting and reflection off the underside of the ice significantly degrade the range from the $500+\mathrm{km}$ expected in ice-free conditions. Comparisons between GPS and acoustically derived positions collected during operations in ice-free conditions suggest $1-2 \mathrm{~km}$ uncertainty in the acoustically derived positions. The first successful section across the ice-covered Davis Strait occurred in 2006, while the first full mission took place in September-February 2008. Mission duration was 25 weeks, with more than $800 \mathrm{~km}$ of under-ice transit over 51 days. The glider was able to identify and surface through leads 10 times during under-ice operations (Beszczynska-Möller et al., 2011). Subsequently, a pair of successful missions collected continuous sections across Davis Strait from October 2010 through June 2011, including operations between January and June, when the Strait was nearly entirely icecovered and the glider rarely gained access to the surface. These missions provide the first year-round time series of high-resolution sections across Davis Strait.

As part of the DAMOCLES/ACOBAR project, the glider navigation system developed for Davis Strait was applied in Fram Strait, with the expectation of future under-ice missions to augment the existing moored array. The glider navigation system for Fram Strait employed navigation signals broadcast from $260 \mathrm{~Hz}$ RAFOS sources and tomographic sources (Sagen et al., 2011; Sandven et al., 2013). Navigation ranges up to $300 \mathrm{~km}$ were achieved in the partially icecovered area, covering the entire width of the deep Fram Strait. However, the acoustically derived positions in Fram Strait differed from GPS-based positions by about $4-8 \mathrm{~km}$, which is a significantly higher error level than was measured in the Davis Strait experiment. This result was mostly due to the low number and suboptimal performance of available RAFOS sound sources. As a result, only short under-ice excursions of Seagliders were performed in Fram Strait, while more attention was paid to testing and evaluation of RAFOS transmissions between sources located in the ice-covered area and gliders moving in open water and the marginal ice zone.

In the Antarctic, ARGO floats are traceable at distances of up to $600 \mathrm{~km}$ under the ice by use of RAFOS signals at $260 \mathrm{~Hz}$ (Klatt et al., 2007). In combination with ice-sensing algorithms, the floats have spent up to seven years in seasonally ice-covered regions.

The next steps include improvement of existing midfrequency systems, first by implementing broadband signals and receivers to improve geolocation accuracy, as proposed by Duda et al. (2006) and partially demonstrated by Freitag et al. (2012). The Marginal Ice Zone (MIZ) Program supported by the U.S. Office of Naval Research included the development of a new mid-frequency $(890 \mathrm{~Hz})$, broadband navigation aid that includes low-bandwidth telemetry, thus allowing the sources to drift freely and report their current positions (Fig. 3). This program was completed in September 2014, and mid-frequency navigation and communication were demonstrated to $400 \mathrm{~km}$ ranges by geolocating an array of gliders and floats in the MIZ (Webster et al., 2015).

As part of DAMOCLES, ACOBAR, and the French integrated Arctic Ocean Observing System project, an advanced ice-tethered platform (AITP) is under 


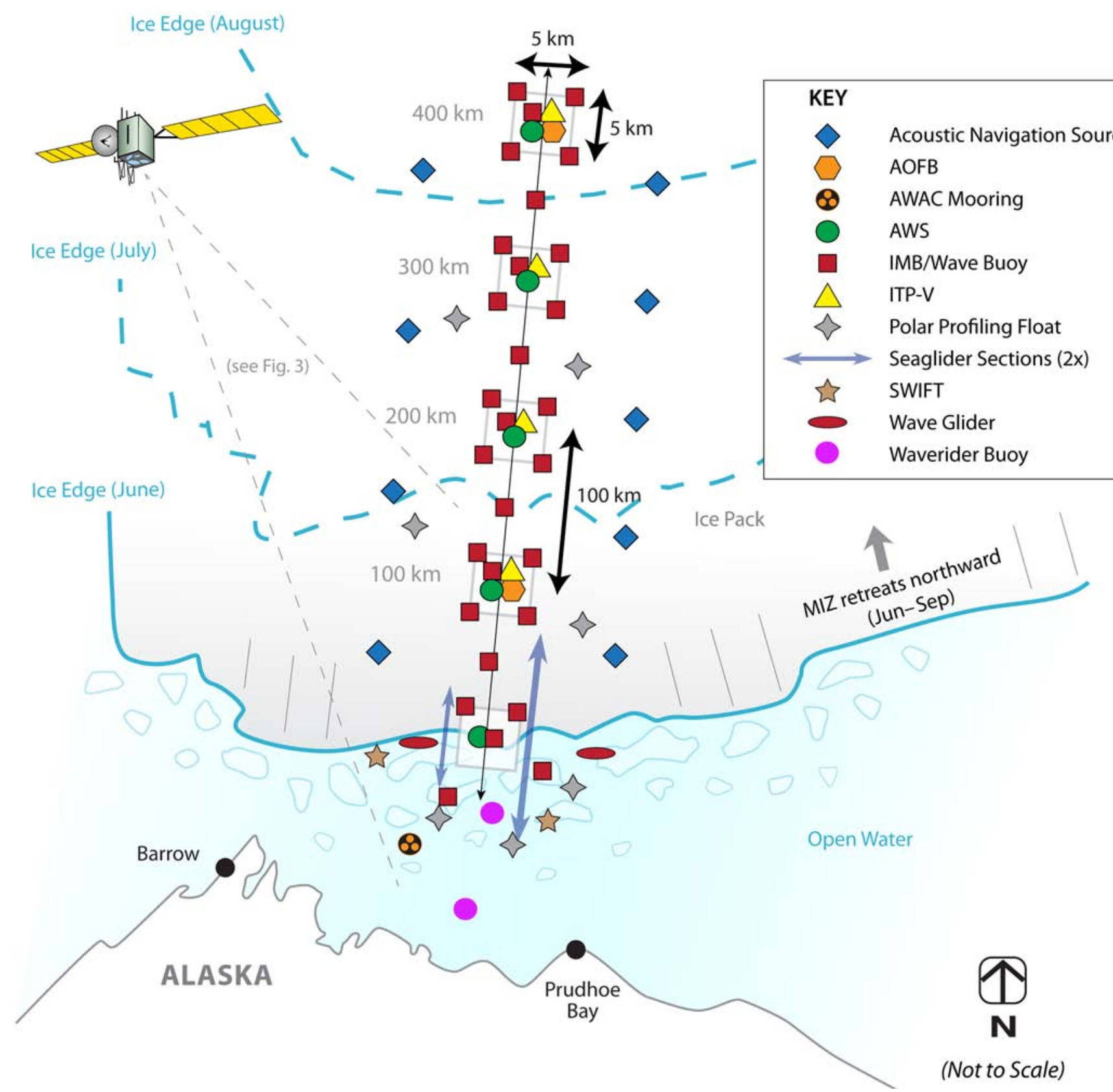

FIG. 3. Schematic of the ice-edge and "five-dice" Ice Mass Buoy/Wave Buoy sub-array configuration used in the 2014 field campaign of the MIZ program. Oceanographic sampling was done by various ice-based instruments that penetrate through the ice-arrays of autonomous weather stations (AWS), ice-tethered profilers (ITP-V), and autonomous ocean flux buoys (AOFB) — and by floats and gliders beneath the ice that are geolocated by acoustic navigation sources at the edges of the observing array. Gliders' sections extend from full ice cover through the MIZ and into open water. Wavegliders and surface wave instrument floats with tracking (SWIFT) drifters sample within the MIZ and the open water to the south, where a bottom-anchored acoustic wave and current (AWAC) mooring was deployed. (Courtesy of C. Lee.)

development for regional implementation in the central Arctic Ocean (Gascard, 2011). The AITPs are currently equipped with $1560 \mathrm{~Hz}$ and $780 \mathrm{~Hz}$ sound sources to provide acoustic navigation of and communication with gliders and floats operating under ice. The AITPs are planned to be deployed in clusters of three to five covering areas of at least $100 \mathrm{~km} \times 100 \mathrm{~km}$ and up to $200 \mathrm{~km} \times 200 \mathrm{~km}$, depending on acoustic frequency. Recent studies indicate that navigation signals from clusters of AITPs can also possibly be used for regional first-order acoustic tomography
(Skarsoulis and Piperakis, 2009). In the near future, the acoustic sources will be mounted on the CTD profiler, which measures temperature and salinity from surface to $1000 \mathrm{~m}$ depth. In this way acoustic propagation conditions and optimal receiving conditions can be obtained in real time by parking the CTD profiler carrying the acoustic source at an optimal depth for transmission of navigation signals to gliders and floats. The profiler transmits data to a surface buoy using an inductive modem, providing nearreal-time capability through satellite communication. The 
integrated system of AITPs, gliders, and floats will sample the upper and lower haloclines, in addition to the surface freshwater layer, the intermediate Pacific layer (shallow), and the Atlantic layer (deep). This scope is important for understanding the interaction between the ocean and sea ice and the heat flux from the ocean to the sea ice. Recently, the AITP has been extended to include atmospheric observations.

\section{Ambient Noise and Bioacoustics in the Arctic}

The anticipated increase of human activities in the Arctic will lead to higher noise levels, e.g., from shipping, seismic exploration, fishing vessels, oil and gas exploration and development, and leisure and research activities (Fig. 4) (Moore et al., 2012a). It is important to document the existing ambient noise characteristics and to detect changes in frequency, amplitude, and intensity in order to investigate and understand any influence on marine mammals in the Arctic (Huntington, 2009). Non-biologic noise from ice-generated processes, such as ridging and cracking, has traditionally been the dominant mechanism contributing to the general character of Arctic ambient noise from a few tenths of $\mathrm{Hz}$ up to $10000 \mathrm{~Hz}$ (e.g., Mikhalevsky, 2001) and has long been used as an indicator of ice conditions and ice rheology. When the ice pack "locks up" and isolates the water from the atmosphere, ambient noise levels can be low compared to levels in the temperate seas. In contrast, the levels are much higher when the wind stress is high, causing ridging, breakup, and broken pack ice. Both locally and basin-wide, the ambient noise is a key indicator of wind stress and surface mixing. At the ice edge, ocean waves and swell propagate from the open ocean into the ice, causing individual floes to break up and, in combination with on-ice wind conditions, increasing the internal stress in the ice field. Under these conditions, the marginal ice zone is a noisy region (e.g., Johannessen et al., 2003; Sagen et al., 2014). It is expected that the future character of Arctic ambient noise, emerging in response to changing ice coverage and thickness, changing weather, and increasing anthropogenic activities, will be quite different. Seismic exploration off the coast of Norway (on the order of $1400 \mathrm{~km}$ away) is observed in the marginal ice zone of Fram Strait (e.g., Fig. 4) (Tollefsen and Sagen, 2014). Furthermore, climate-driven changes such as the breakup of ice shelves and icebergs can be remotely monitored by passive acoustic observation of ocean ambient noise (Gavrilov and $\mathrm{Li}, 2007$ ).

Historically, observations of marine mammals in the Arctic were mainly from ships and aircraft, so data are sparse in time and space. Marine mammals use sound for sensing their environment (passive listening) and for social communication (Clark et al., 2009). In addition, odontocetes (toothed whales and dolphins) use echolocation for foraging and navigation. Mounting autonomous acoustic recorders on fixed moorings, floats, gliders, and AUVs provides the means for systematic sampling of the seasonal occurrence

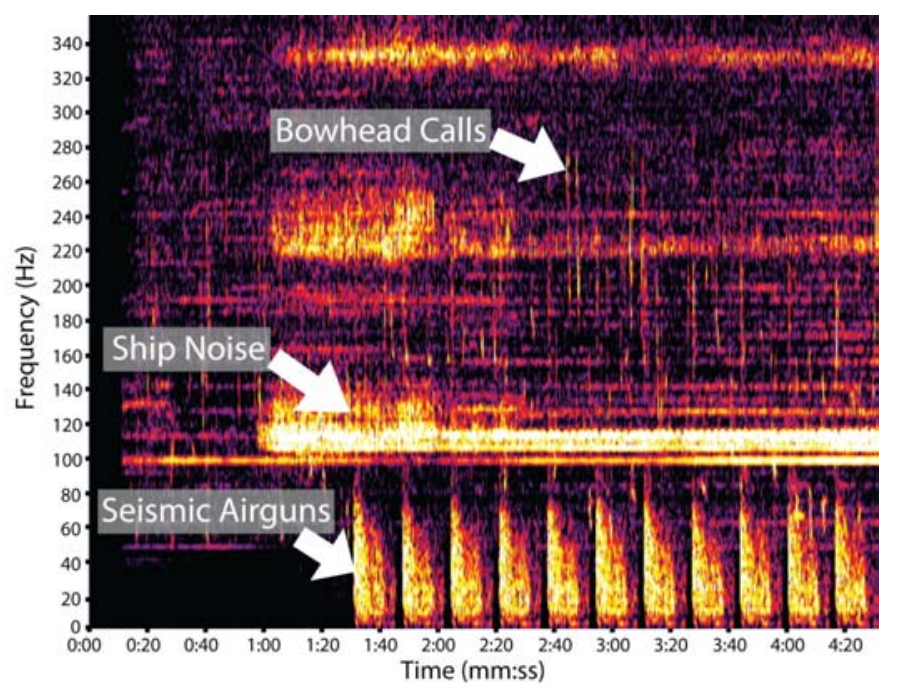

FIG. 4. Spectrograms showing bowhead calls, a ship transiting, and airgun pulses from seismic surveys. (Figure from Moore et al., 2012a, $\odot$ American Institute of Biological Sciences; reproduced with permission.) All three types of signals are ubiquitous in Fram Strait, where bowheads were discovered to sing complex songs in winter (Stafford et al., 2012).

of vocal cetaceans (Mellinger et al, 2007), opening a window onto the large-scale seasonal movements and habitat selection of Arctic marine mammals (Moore and Huntington, 2008).

Passive acoustic monitoring has been used since the early 1980 s to study the migration of bowhead whales (Balaena mysticetus) in the western Arctic (e.g., Blackwell et al., 2007). Since 2008, over 100 recorders have been deployed annually offshore Alaska. Most are in the service of industry to measure sound fields and detect marine mammal calls near offshore oil and gas exploration (e.g., Blackwell et al., 2007; Mouy et al., 2012), while others were deployed for the purpose of integrated ocean observation (e.g., Stafford et al., 2013). To date, analyses of data from these deployments have been done on a project-by-project basis, but data from 20 recorders in the Beaufort and Chukchi Seas have now been combined to generate a synthesis of the acoustic soundscape under the auspices of the Synthesis of Arctic Research program (http://www.arctic.noaa. gov/soar/). Ideally, this synthesis will be a step in the direction of planning a more efficient and integrated network of recorders for the purpose of measuring ambient and bioacoustic sound in the Arctic. Including recorders on oceanographic moorings (e.g., Moore et al., 2012b) and on gliders (e.g., Baumgartner and Fratantoni, 2008) will provide additional synergies with a multipurpose acoustic network.

In 2008, passive recorders were deployed in Fram Strait on oceanographic moorings along the $78^{\circ} 50^{\prime} \mathrm{N}$ latitude line at $4^{\circ} \mathrm{W}$ and $1^{\circ} \mathrm{E}$, as part of an IPY project to develop underwater sound budgets for Arctic waters (Moore et al., $2012 b)$. This data set is the first long-term recording of ambient sound in Fram Strait. In addition to calls from blue and fin whales (Moore et al., 2012b), complex songs from bowhead whales were recorded throughout the winter (Stafford et al., 2012), suggesting that Fram Strait is a wintering 
ground - and potentially a mating area-for this critically endangered population of bowhead whales. Plans for continuation of this work have been proposed via the Norwegian Polar Institute. In addition, recorders were deployed during 2009 in Fram Strait and the Greenland Sea, where blue and fin whale calls provided a strong seasonal signal at both sites. Sperm whale signals were also detected in Fram Strait (Klinck et al., 2012). Of note, airgun sounds from seismic surveys associated with oil and gas exploration were ubiquitous in Fram Strait, as reported in both studies (Klinck et al., 2012; Moore et al., 2012b) (Fig. 4).

Recent research has focused on methods for automated detection and classification of marine mammal calls (e.g., Baumgartner and Mussoline, 2011) and for estimating the population density of cetaceans from passive acoustic recordings (Marques et al., 2009; Küsel et al., 2011; Kyhn et al., 2012; Ward et al., 2012). These methods rely on counting the number of calls detected, estimating the probability of detecting a call as a function of distance, distinguishing calls from different individuals, and measuring the average call rate. The result is an estimate of the number of animals (or groups) per unit area for the region monitored by the passive acoustic sensors. Acoustic models used for ranging and tracking of marine mammals require accurate knowledge of the sound speed profile, and monitoring systems of marine mammals will therefore benefit from integration with the acoustic tomography systems.

\section{Monitoring Seismicity in the Arctic}

Acoustic networks can be deployed together with broadband seismometers. These seismometers are useful for studying the solid earth on local (up to tens of kilometres), regional (tens to hundreds of kilometres), and global scales. The seismometers may be deployed on the ice or, preferably, on the seafloor. The deployment of seismometers in the Arctic, whether for temporary experiments that may last up to several months or for longer-term experiments, would provide invaluable data to the scientific solid earth community (Atakan et al., 2015). Bathymetric maps of the Arctic show several enigmatic geological features. The Gakkel Ridge, for example, is one of the earth's two ultraslow spreading ridges, and the creation of new crust at the ridge, through volcanism and tectonic faulting, is poorly understood. While the evolution of the Eurasian Basin is generally known, the evolution of the Amerasian Basin is controversial (Shephard et al., 2013). Other features of the Arctic, such as the Lomonosov Ridge and Chukchi Shelf, are even less well understood. A better understanding of the geodynamic history of these and other Arctic areas not only is important from an earth science perspective, but could also help in the resolution of territorial disputes and the assessment of mineral resources. Figure 5 shows epicentres of earthquakes of magnitude 4 and higher during the period 1900-2013. Most of the seismicity is concentrated along the Knipovich and Gakkel Ridges. For these local and regional studies, it is essential that both active and passive

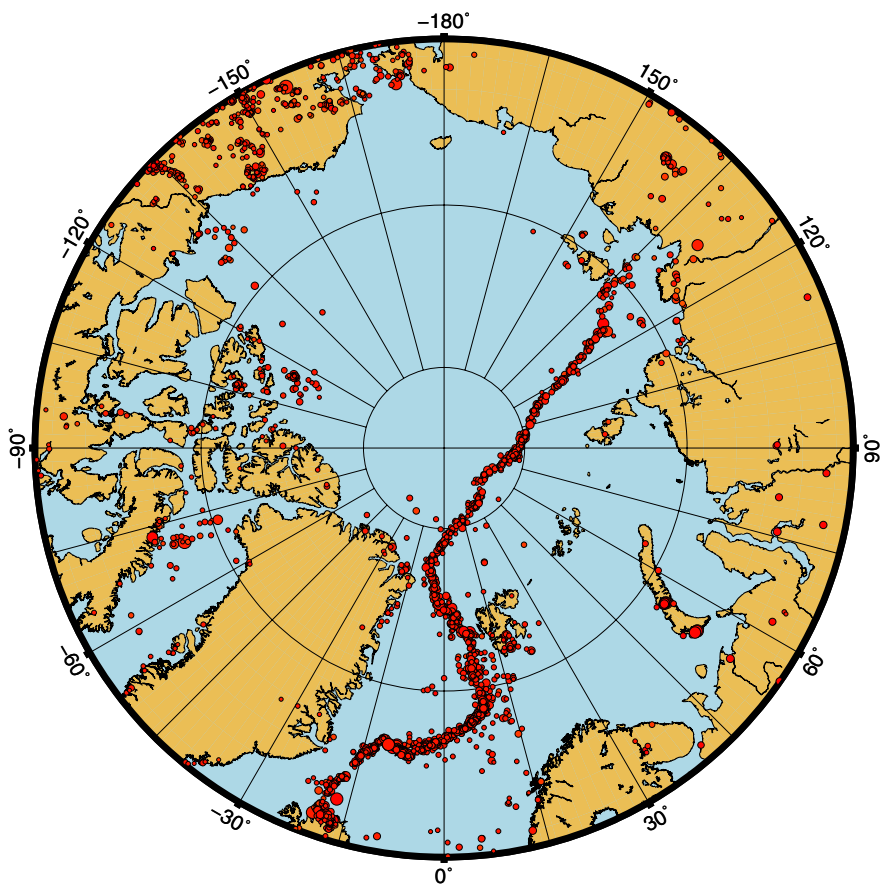

FIG. 5. Epicenters of earthquakes with magnitude 4 and higher in the Arctic and Subarctic regions, 1900-2013. Most of the seismicity is concentrated along the Knipovich and Gakkel Ridges. (Courtesy of M. Raeesi, University of Bergen.)

(i.e., earthquake) source seismic experiments be conducted in the Arctic. The broadband seismometers will also provide valuable data for the study of global earthquakes and global earth structure. Most seismometers used in global seismology are based on land. Earthquake recordings from the Arctic will therefore provide improved constraints on the estimation of the mechanisms of large earthquakes. These constraints are important for tectonic and seismic hazard studies. Moreover, these data will help improve global tomographic models of the mantle. These models are used to study and constrain tectonic processes on a global scale.

\section{Fram Strait Multipurpose Acoustic Network}

The Fram Strait is a key location to study the impact of the Arctic Ocean on global climate. The Strait, with a sill depth of $2600 \mathrm{~m}$ and a width of nearly $400 \mathrm{~km}$, is the only deep connection where exchanges of intermediate and deep waters take place between the North Atlantic and the Arctic Ocean. On the eastern side of the Strait, the northbound West Spitsbergen Current transports Atlantic water into the Arctic Ocean, whereas on the western side, the southbound East Greenland Current transports sea ice and polar water from the Arctic Ocean to the Nordic Seas and the Atlantic Ocean. Between these two main current systems, Atlantic water recirculates westward and subsequently returns southward along several pathways without entering the Arctic Ocean. Atlantic water recirculation is characterized by strong mesoscale variability and frequent occurrences of baroclinic eddies with diameters on the order of $10 \mathrm{~km}$ 
and timescales from a few days to a few weeks. Typically mesoscale eddies extend down to the lower boundary of the Atlantic water layer $(600-800 \mathrm{~m})$.

Since 1997 an array of 16-18 oceanographic moorings has been maintained by the Alfred Wegener Institute and the Norwegian Polar Institute in the northern part of Fram Strait at $78^{\circ} 50^{\prime} \mathrm{N}$, covering the strait between the East Greenland shelf and the shelf slope west of Svalbard (Fig. 1; Beszczynska-Möller et al., 2011, 2012). In spite of the number of moorings and instruments (and that there is only a single line of moorings across the strait), the flow is undersampled, given the short spatial scales in Fram Strait. The array is not sufficient to estimate the effects of the intense mesoscale variability, the effects of the strongly variable recirculation of Atlantic Water, and the strong contribution from the surface layer. The contribution of measurement noise is significant in the current flux estimates, up to $50 \%$ to $100 \%$ (Fahrbach et al., 2001). As a result, the mass and heat budget of the Arctic Ocean cannot be balanced, because the uncertainties in the Fram and Davis Strait fluxes are larger than the total fluxes through the other gateways (Beszczynska-Möller et al., 2011).

DAMOCLES was an integrated EU/FP6 project (2005-10) aimed at observing, understanding, and quantifying climate changes in the Arctic. The Arctic is a harsh environment, and the ice cover prohibits the use of many conventional instruments, data transfer methods, and calibration schemes. Acoustic thermometry was selected by DAMOCLES as a promising technology to provide integral properties of the inflowing and outflowing water masses in Fram Strait, while gliders were chosen to provide highresolution measurements of the complex oceanographic fields. A prototype ocean acoustic tomography system was deployed by the Nansen Environmental and Remote Sensing Center (NERSC) from 2008 to 2009 to measure the average temperature (heat content) in the eastern half of the Strait (West Spitsbergen Current), taking advantage of the integrating property of the acoustic measurements (Sagen et al., 2008, 2011). Figure 6 shows the location and the range- and depth-averaged temperature with an accuracy of $50 \mathrm{~m}^{\circ} \mathrm{C}$ as obtained by inversion of the acoustic travel times. The inversion scheme is based on vertical empirical orthogonal functions derived from the high-resolution ice ocean model developed within DAMOCLES. Due to the properties of the ocean environment in Fram Strait, the well-known inversion approaches applied at lower latitudes cannot be used. The weak vertical sound speed gradient in the West Spitsbergen Current and the strong oceanic variability (e.g., eddies, fronts) cause the multipath acoustic arrivals to overlap in time and result in peaks roughly $100 \mathrm{~ms}$ in width. This makes resolution and identification of individual ray arrivals impossible. Therefore, a new strategy for comparing observed and predicted acoustic arrival patterns has been developed allowing for inversions (H. Sagan, unpubl. data). The inversion results in Figure $6 \mathrm{~b}$ are in good agreement with the results obtained by another inversion technique developed by Skarsoulis et al.
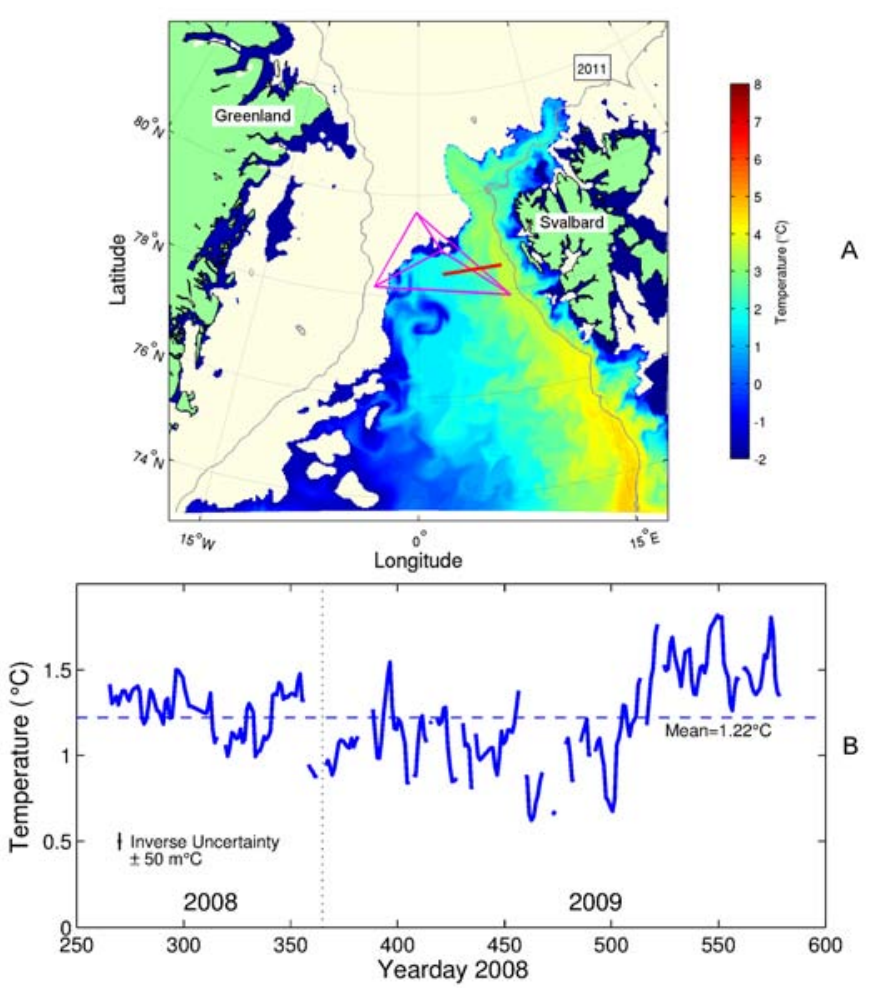

FIG. 6. A) The tomographic systems deployed in Fram Strait overlaid on seasurface temperature and approximate ice coverage determined by the highresolution Fram Strait model (HYCOM) at Nansen Center. DAMOCLES consisted of a single line (red), while ACOBAR consisted of a triangular array (magenta). Ice coverage was defined by a surface temperature lower than $-1.7^{\circ} \mathrm{C}$. B) A year-long time series of average temperature determined by DAMOCLES tomography with an accuracy of about $50 \mathrm{~m}^{\circ} \mathrm{C}$. Temperature is averaged over depths of 0 to $1000 \mathrm{~m}$ and the $130 \mathrm{~km}$ range of the DAMOCLES track. The tomographic measurements resolved the scintillations in heat content arising from the advection of mesoscale features across the acoustic path by the West Spitsbergen Current. (Courtesy of the ACOBAR project, H. Sagen, and B. Dushaw.)

(2010). The agreement in the inversion results using different approaches demonstrates the robustness of the acoustic measurements. Acoustically derived depth-averaged temperatures have also been used for validation of ice-ocean models (Sandven et al., 2013).

Subsequently, ACOBAR (2008-12), a collaborative EU/FP7 project coordinated by NERSC, capitalized on the experience, knowledge, and monitoring technologies developed within DAMOCLES. Three moored acoustic transceivers were deployed from 2010 to 2012 in a triangle with a moored receiver in the center (Figs. 1,6). This geometry gave a total of six acoustic paths that covered the Fram Strait Marginal Ice Zone, compared to the single acoustic path during DAMOCLES. The acoustic transceivers also transmitted RAFOS signals to provide an underwater acoustic navigation system for gliders and floats. A Seaglider operated by the Alfred Wegener Institute used the acoustic signals to test navigational solutions in the open water and for a short mission under the ice. This experiment was the first implementation of a multipurpose acoustic network for tomography, passive acoustic monitoring, and navigation of gliders. The primary goal is to estimate 
the heat, mass, and freshwater transport through Fram Strait more accurately by using a four-dimensional data and model system that combines acoustic travel time measurements and ocean data from gliders and moorings with highresolution ice-ocean modeling through data assimilation. Another goal is to observe and explain changes in ambient noise with respect to changes in environmental conditions and increased human activities (Sagen et al., 2011; Haugan et al., 2012; Sandven et al., 2013).

As part of the Arctic Ocean UNDER melting ICE (UNDER-ICE) project (2013-17) funded by the Research Council of Norway, the Fram Strait multipurpose acoustic network will be continued and extended northward to cover the central part of the Strait between $78^{\circ} \mathrm{N}$ and $80^{\circ} \mathrm{N}$. The acoustic network will be upgraded with new receiver technology that allows for beamforming (Worcester et al., 2009, 2013) and augmented with oceanographic sensors. In addition, the development of drifting multipurpose systems has been proposed for the High Arctic and marginal ice zones based on the receiver technology used in UNDERICE (Worcester et al., 2009), lighter mid-frequency, broadband acoustic sources (e.g., Morozov et al., 2012), a short baseline acoustic positioning system for the hydrophones, and near-real-time transfer of pre-processed acoustic data. The drifting tomography system will be integrated with the UNDER-ICE moored system. The UNDER-ICE observing system is a component of the Svalbard Integrated Arctic Earth Observing System (SIOS) (e.g., Ellis-Evans et al., 2013).

\section{TOWARDS A BASIN-WIDE ARCTIC ACOUSTIC NETWORK}

\section{Impact of a Changing Arctic on Acoustic Networks}

The Arctic Ocean continues its unprecedented transition towards an ice-free state. The smallest sea ice extent ever recorded in the Arctic Ocean was observed in 2012, eclipsing the previous record set in 2007. The five smallest extents in the satellite record have occurred in the last seven years (http://nsidc.org/). These large changes in the extent and composition of the Arctic sea ice, particularly the loss of the thick multiyear ice, are expected to affect acoustic propagation. Submarine measurements from 1957 to 2000 and satellite measurements from 2003 to 2008 show a $65 \%$ reduction in multiyear ice extent and a $48 \%$ reduction in average sea ice thickness ( $3.64 \mathrm{~m}$ to $1.89 \mathrm{~m}$ ) over the last 40 years, and more than half the total loss of multiyear ice has occurred in the last 10 years (Kwok and Rothrock, 2009; Maslanik et al., 2011; NRC, 2012). In 2013 and 2014, sea ice extent increased by $50 \%$ relative to the 2012 minimum, and multiyear thick ice increased by $5 \%-10 \%$. Nonetheless, ice extent and the amount of multiyear ice are still well below the 1981-2010 average. The Arctic is clearly in a highly variable state, which only reinforces the need for persistent and long-term observations.
The ice cover traditionally has insulated the Arctic Ocean from solar and atmospheric warming and cooling, creating and maintaining a stable upward refracting sound speed profile. Propagation loss in the Arctic half-channel bounded on the top by rough multiyear sea ice is dominated by the scattering and coupling of acoustic energy as it interacts with the ice cover. The loss is highly frequencydependent, increasing exponentially with frequency and creating a low-pass filter (Mikhalevsky, 2001). The roughness of the ice is directly proportional to the thickness; thus, the thinner ice in the current Arctic is expected to reduce the propagation loss at higher frequencies, permitting use of higher-frequency sources that would be smaller and less costly than the $20 \mathrm{~Hz}$ sources used in the TAP and ACOUS experiments (Mikhalevsky, 2011). In addition to transmission loss, the nature, extent, and rate of change of ambient noise, spatial and temporal signal coherence, and coupling of acoustic modes and Arctic water masses are not known. Modeling has been performed, and estimates of these changes on acoustic propagation have been made; however, in situ multi-frequency measurements as a function of range are needed.

In order to understand these changes, an acoustic propagation experiment, the THin-ice Arctic Acoustic Window (THAAW) experiment, was carried out on the pack ice in the Arctic Ocean from April 2013 through April 2014 by Science Applications International Corporation (now Leidos, Inc.). Acoustic transmissions from 40 to $200 \mathrm{~Hz}$ were made between an acoustic source and a $600 \mathrm{~m}$ 32-element vertical line receive array, both deployed in the High Arctic from ice floes drifting with the pack ice. Because of unfavorable ice conditions and weather, only a small portion of the data was recovered and analyzed, but these data were insufficient to quantify the acoustic propagation loss. Scripps Institution of Oceanography augmented the Leidos effort with a bottom-moored distributed vertical line array (DVLA) receiver (Worcester et al., 2009, 2013) deployed through the ice close to the Pole in April 2013. The DVLA consisted of a $600 \mathrm{~m}$ array with 22 hydrophone modules. Unfortunately, the mooring failed shortly after deployment and surfaced prematurely. After surfacing, the mooring drifted slowly with the ice southward toward Fram Strait, recording ambient noise, temperature, and salinity data as it drifted. The mooring was recovered in September 2013. The ambient noise data from the drifting array are being analyzed, and plans are in place for summer 2015 that include making the propagation loss measurements that were the goal of the THAAW experiment. These data are essential to understand acoustic propagation in the Arctic today and to inform the design of the lower-frequency acoustic networks needed for regional and basin-scale coverage.

\section{Environmental Regulatory Issues}

Almost every human activity that occurs in the ocean produces underwater sound, either purposefully or as a 
by-product. The infrastructure necessary for a basin-wide acoustic network includes acoustic sources that would enable acoustic thermometry, tomography, communication, and navigation, in addition to passive receivers, floats, and autonomous vehicles. Animals that are exposed to underwater sound may experience acute short-term effects, such as temporary threshold shift or behavioral reaction, or chronic long-term effects, such as masking of biologically important vocalizations (Clark et al., 2009; Ellison et al., 2012). U.S. researchers that produce underwater sound are required to evaluate the potential environmental effects in order to comply with the National Environmental Policy Act, the Marine Mammal Protection Act, and the Endangered Species Act, to name the most common laws that must be considered (http://www.nmfs.noaa.gov/pr/ acoustics/guidelines.htm). Projects funded by the European Union (EU) must evaluate the impulsive and ambient noise indicators that define Good Environmental Status under the EU Marine Strategy Framework Directive (EU Marine Strategy Framework Directive, 2008; Van der Graaf et al., 2012).

Several acoustic tomography projects have undergone extensive environmental review in the United States, most notably the Acoustic Thermometry of Ocean Climate (ATOC) project and the North Pacific Acoustic Laboratory (NPAL) project that followed it. The sources used during ATOC and NPAL were designed to be received throughout the North Pacific, with coded transmissions to enable their detection at received levels below that of the ambient noise. Prior to the deployment and operation of these sources, U.S. environmental impact statements were developed and associated permits for incidental harassment were obtained from National Oceanic and Atmospheric Administration (NOAA) Fisheries. Because of the limited data on animal sensitivities to underwater sound at the time, initial operations of the ATOC sources were accompanied by extensive environmental studies to investigate the potential for effects on marine mammals, sea turtles, and fishes. There were no obvious effects due to the sound sources, but some subtle effects were detected. For example, the distance and time between successive humpback whale surfacings north of Kauai increased slightly with increasing sound levels (Frankel and Clark, 1998). However, the observed effects were all within the natural range of variability. The authors concluded that the minor effects that they observed were not biologically significant.

Prior to the deployment of active acoustic sources for the ACOBAR experiment, an acoustic and environmental analysis (Environmental Assessment Report, EAR) was conducted under the auspices of the EU Marine Strategy Framework Directive to determine the potential for impact on the marine environment associated with the experiment's activities and use of underwater active acoustic sources (http://acobar.nersc.no). Because of the low source level of the acoustic sources, their placement in relationship to Marine Protected Areas (MPAs), and the long intervals between transmissions, no effects were expected on any
MPA or any marine species listed as endangered or threatened under the U.S. Endangered Species Act or as threatened (vulnerable, endangered, threatened, or critically endangered) by the International Union for Conservation of Nature. In addition, no reasonably foreseeable behavioral responses of marine mammals (under the U.S. Marine Mammal Protection Act) were expected as a result of this experiment. The conclusion resulting from the scientific analysis of the ACOBAR experimental activities was that no ethical issues were reasonably foreseeable, as the experiment has no potential for causing grave danger to marine mammals potentially occurring in the Fram Strait region. A secondary, final EAR will compare measured acoustic propagation conditions during the ACOBAR experiment with previous predictions. It will also update the marine mammal distribution and abundance information with any new data and summarize future ocean observing plans and their potential impact on the Arctic marine environment.

\section{An Arctic Ocean Observatory}

The possibility of cabling a number of acoustic sources and sensors was discussed in the Abstract and Introduction. While cabling sources and sensors can provide power and communications to a few sites, the operation of an observatory on climate scales of $25-30$ years would be best supported through a network of seafloor cables, which would minimize the life-cycle costs by providing power, communications, and command-and-control through the backbone network (Schofield et al., 2010; ITU/WMO/UNESCO IOC Joint Task Force, 2012).

We propose that a seafloor cabled network such as that shown in Figure 7 be built in the Arctic in order to provide near-real-time (latencies of seconds) access to data, instruments, and platforms in the critical Arctic environment as it undergoes unprecedented change associated with climate and a warming earth. While cables are expensive to install, the life cycle costs over a climate cycle (e.g., 30 years) are substantially less than those of alternative solutions, including autonomous seafloor moorings, ice camps, and shipborne expeditions. Cables would be important not only to support scientific research, but also to provide high bandwidth connectivity to Arctic communities to significantly enhance connectivity, safety, and security. Because of the cost of deploying cable, installation of scientific and communications cables in the Arctic should be coordinated.

We expect to use an advanced data, instrument, and platform cyberinfrastructure developed for the National Science Foundation (NSF) Ocean Observatories Initiative (OOI), which can be readily implemented in a broad Arctic Observing Network (AON). The OOI cyberinfrastructure exploits modern networking, computing, and cloud technologies in an Ocean Observatories Initiative Network (OOINet). The system delivers open data to users in near real time. It is simple to develop virtual observatories by subscribing to data from individual platforms and instruments; the system can be expanded to serve thousands of users and 


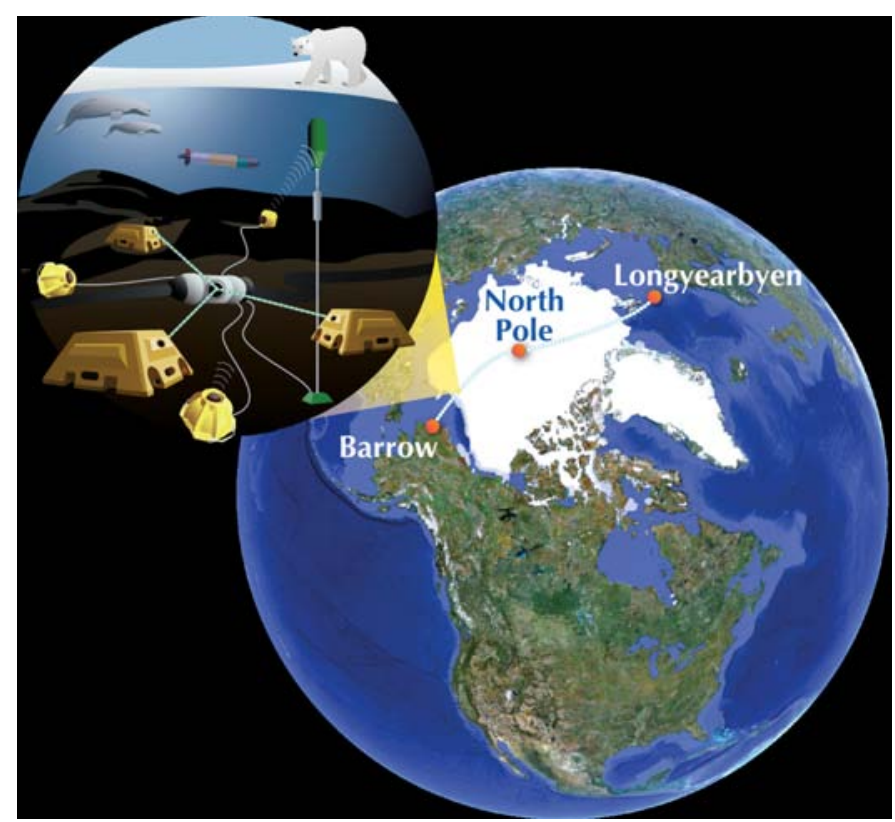

FIG. 7. A notional cabled network in the Arctic Ocean with a variety of instruments at each node, including systems moored above the seafloor, but below the ice. In this case, the bottom-moored system represents an acoustic thermometry transducer surrounded by three short-range seafloor transponders for locating the position of the transducer accurately. The other instruments in the vicinity represent additional sensors and docks for autonomous vehicles. The cable comes ashore at two points in order to provide redundancy if the primary cable is cut or a failure occurs at one of the repeaters located every $75 \mathrm{~km}$ along the route. Each repeater provides a breakout opportunity for a mini-observatory with a wide variety of measurements. (Courtesy of J. Orcutt.)

virtual observatories. In addition, because the connections to the platforms and sensors are duplex, the user or operator can use the network to provide command and control capabilities.

The OOI cyberinfrastructure uses an open-source message passing protocol (AMQP; https://www.amqp.org) for message passing to and from individual sensors and platforms (e.g., gliders and AUVs). This implementation, which substitutes point-to-point messaging for Internet protocols, provides a means for the high levels of cybersecurity needed to ensure that the system, platforms, and instruments cannot be hacked by exploiting the well-known structure of the Internet. Another important feature of the cyberinfrastructure is that it deploys instrument agents for each platform and sensor so that every element of the observatory has a common interface, allowing powerful integration of a large, heterogeneous, deployed network.

The proposed architecture includes the possibility for others to offer data and products to the system. That is, the proposed AON observatory can seamlessly integrate other existing or planned Arctic observatories. Sharing sensor and data networks, including data persistence far into the future (i.e., archiving data as well as sensor descriptions and operations) offers economies of scale in addition to the chosen cabled network's low life cycle costs.

\section{CONCLUSIONS, STATUS AND ROADMAP}

The development of a multidisciplinary, integrated, synoptic Arctic Ocean observing system, capable of performing sustained regional- to basin-scale observations of the ocean interior under ice, is needed to support research that will better our understanding of the dramatic changes occurring now and improve our ability to respond to this change as the Arctic Ocean evolves to a seasonally ice-free state (e.g., Haugan et al., 2012). Integrating multipurpose acoustic networks into the observing system will provide basin-wide and regional tomography and thermometry observations; navigation for gliders, floats, and UUVs under ice; and passive acoustic listening. The in situ observations, together with acoustic and satellite remote sensing, will provide comprehensive oceanographic data for climate and environmental monitoring and integrated oceanice-atmosphere modeling employing data assimilation for improved predictions of the changing Arctic. Passive acoustic observations, which over time provide long-term data on ice dynamics, Arctic basin seismicity, human activities, and marine mammals, are a key capability of the acoustic systems.

Acoustic receiving systems for application in multipurpose acoustic networks are now straightforward. Compact, solid-state memories that provide gigabytes of storage are readily available. Low power Chip-Scale Atomic Clocks (CSACs) provide the accurate timekeeping needed for acoustic tomography and navigation, even for fully autonomous subsurface instruments. Acoustic sources, however, are still an issue for basin-scale, low-frequency systems. As noted above, as a result of the changing characteristics of the Arctic ice cover, sources likely no longer have to transmit at $20 \mathrm{~Hz}$ or below to achieve long ranges, as was the case only a few decades ago. Nonetheless, it is likely that frequencies of $100-200 \mathrm{~Hz}$ (or perhaps even lower) will still be required. Sources are available at these frequencies, but the development of improved low-frequency, broadband sources would be highly desirable (e.g., Morozov et al., 2011, 2012; Mosca et al., 2013). One advantage of applications of acoustic remote sensing in the Arctic is that the acoustic source can operate at shallow depths and still illuminate the entire water column, because the sound channel axis is at the surface.

There are no regulatory impediments to the use of acoustic sources that are being envisioned for the Arctic acoustic networks, and a permitting process is in place for the support of future activities.

Servicing of the acoustic transceivers needed for multipurpose acoustic systems is logistically challenging in the Arctic. A basin-scale system for tomography, navigation, passive listening, and communication under ice would consist of a relatively small number of low-frequency transceivers $(<10)$, making it potentially feasible to cable the moorings to shore (Lee and Gobat, 2006; ANCHOR Working Group, 2008). This approach would remove batteries as a limiting factor, allowing the moorings to be designed to 
remain in place for 5-7 years (or perhaps even longer) and greatly reducing the frequency with which they would need to be serviced by icebreakers or other ships.

Cabling of the instruments would also provide yearround, real-time, high-bandwidth communications with shore and supply power for video systems, profiling instruments, wide band hydrophones and seismometers, and the charging of unmanned vehicles (Fig. 7). Cable and cable installation are costly. It would make sense to build the cabled system over several years, beginning with selected key nodes proximal to shore and expanding to connect autonomous moorings deeper in the Arctic basin or planned regional networks, such as a Beaufort Sea observing system, the Fram Strait Ocean Observatory, or the existing deep seafloor observatory HAUSGARTEN (AWI, 2014).

We recommend that:

1) A multiyear development and implementation plan for multipurpose acoustic network infrastructure that includes international participation be completed. Like the NSF Ocean Observatories Initiative (NSF OOI, 2013; http://oceanobservatories.org/) Regional Scale Nodes (RSN), and Ocean Networks Canada (http://www.oceannetworks.ca/), this network could start with one or two cabled nodes. For example, the first nodes could be in the Beaufort Sea off the North Slope of Alaska or coordinated with the Svalbard Integrated Earth Observing System in Fram Strait.

2) The technology and lessons learned from the subsea infrastructure being deployed for the OOI RSN and the subsea infrastructure used by oil companies in the sub-Arctic regions be transferred into the Arctic.

3) Partnerships be developed with other observing programs that will benefit from cabled infrastructure in the Arctic, for example, the European Plate Observing System (EPOS), Svalbard Integrated Earth Observing System, and the Fram Strait observing system. Through such partnerships, a broad set of important scientific problems and multidisciplinary research in the Arctic can be studied and the collaboration will reduce overall logistical costs for the scientific communities involved.

4) Partnerships be established with commercial companies operating in the Arctic regions and with communities in the region. Communication cables in the Arctic Ocean would enable efficient communication between different Arctic regions and thereby improve safety and security.

5) Improved low- to mid-frequency sources $(50-500$ $\mathrm{Hz}$ ) be developed to better support basin and regionalscale tomographic, communications, and navigation networks. Multipurpose networks of regional sources and receivers on moored and ice-tethered platforms should be deployed and maintained annually. These deployments should be coordinated with icebreaker expeditions and other logistical capacities that are expected to be available every year in the High Arctic.

6) Acoustic data be integrated with oceanographic and sea ice data, combining spatially integrated measurements from acoustics with point measurements and vertical profiles of physical variables. These data can then be used in modeling and data assimilation systems.

\section{ACKNOWLEDGMENTS}

The authors acknowledge the organizers of the Arctic Observing Summit held in Vancouver, Canada, who invited the submission of the original white paper and encouraged us to submit this paper to Arctic for the special thematic cluster on Arctic Observing. We also acknowledge John Orcutt and Kuvvet Atakan and their co-authors for incorporating key aspects of their Arctic Observing Summit white papers into this paper. Kuvvet Atakan, Henk Keers, and Mo Yan Yuen thank the Norwegian National EPOS Members (L. Bjerrum, H. Bungum, J. Dehls, A. Kaynia, H. Kierulf, T. Kværna, V. Maupin, C. Lindholm, L. Ottemöller and M. Sørensen) for valuable discussions on research in the Arctic. Finally, we thank the reviewers of the manuscript and the editorial staff of Arctic, in particular Karen McCullough and Luisa Alexander Izzo, for the very thorough reviews and editing.

\section{REFERENCES}

ANCHOR Working Group 2008. Acoustic navigation and communications for high-latitude ocean research. ANCHOR Workshop 2006, 27 February-1 March 2006, Applied Physics Laboratory, University of Washington, Seattle, Washington. http://anchor.apl.washington.edu/ANCHOR_workshop_ report_print.pdf

Atakan, K., Bjerrum, L.W., Bungum, H., Dehls, J.F., Kaynia, A.M., Keers, H., Kierulf, H.P., et al. 2015. The European Plate Observing System and the Arctic. Arctic 68(Suppl. 1). http://dx.doi.org/10.14430/arctic4446

ATOC (Acoustic Thermometry of Ocean Climate) Consortium. 1998. Ocean climate change: Comparison of acoustic tomography, satellite altimetry, and modeling. Science 281(5381):1327-1332.

http://dx.doi.org/10.1126/science.281.5381.1327

Avsic, T., Send, U., and Skarsoulis, E. 2005. Six years of tomography observation in the central Labrador Sea. Proceedings of the 1st International Conference on Underwater Acoustic Measurements: Technologies and Results, 28 June-1 July 2005, Heraklion, Greece. 10 p. http://atom007.heimat.eu/pdf/Six_years_of_tomography_ observation_in_the_Central_Labrador_sea.pdf 
AWI (Alfred-Wegener-Institut). 2014. Time-series studies at the deep-sea observatory HAUSGARTEN.

http://www.awi.de/en/research/deep_sea/deep_sea_ecology/ time_series_studies_at_the_deep_sea_observatory hausgarten/

Baumgartner, M.F., and Fratantoni, D.M. 2008. Diel periodicity in both sei whale vocalization rates and the vertical migration of their copepod prey observed from ocean gliders. Limnology and Oceanography 53(5):2197-2209.

http://dx.doi.org/10.4319/1o.2008.53.5_part_2.2197

Baumgartner, M.F., and Mussoline, S.E. 2011. A generalized baleen whale call detection and classification system. Journal of the Acoustical Society of America 129:2889-2902.

http://dx.doi.org/10.1121/1.3562166

Beszczynska-Möller, A., Woodgate, R.A., Lee, C., Melling, H., and Karcher, M. 2011. A synthesis of exchanges through the main oceanic gateways to the Arctic Ocean. Oceanography 24(3):82-99.

http://dx.doi.org/10.5670/oceanog.2011.59

Beszczynska-Möller, A., Fahrbach, E., Schauer, U., and Hansen, E. 2012. Variability in Atlantic water temperature and transport at the entrance to the Arctic Ocean, 1997-2010. ICES Journal of Marine Science 69(5):852-863.

http://dx.doi.org/10.1093/icesjms/fss056

Blackwell, S.B., Richardson, W.J., Greene, C.R., Jr., and Streever, B. 2007. Bowhead whale (Balaena mysticetus) migration and calling behaviour in the Alaskan Beaufort Sea, autumn 2001-04: An acoustic localization study. Arctic 60(3):255-270.

http://dx.doi.org/10.14430/arctic218

Clark, C.W, Ellison, W.T, Southall, B.L., Hatch, L., Van Parijs, S.M., Frankel, A., and Ponirakis, D. 2009. Acoustic masking in marine ecosystems: Intuitions, analysis, and implication. Marine Ecology Progress Series 395:201-222.

http://dx.doi.org/10.3354/meps08402

Duda, T.F., Morozov, A.K., Howe, B.M., Brown, M.G., Speer, K., Lazarevich, P., Worcester, P.F., and Cornuelle, B.D. 2006. Evaluation of a long-range joint acoustic navigation/ thermometry system. Proceedings of the MTS/IEEE Oceans 2006 Conference, 18-21 September 2006, Boston, Massachusetts. 1-6. http://dx.doi.org/10.1109/OCEANS.2006.306999

Dushaw, B.D., Bold, G., Chui, C.-S., Colosi, J., Cornuelle, B., Desaubies, Y., Dzieciuch, M., et al. 2001. Observing the ocean in the 2000's: A strategy for the role of acoustic tomography in ocean climate observation. In: Koblinsky, C.J., and Smith, N.R., eds. Observing the oceans in the 21st century. Melbourne, Australia: GODAE Project Office, Bureau of Meteorology. $391-418$.

Dushaw, B.D., Worcester, P.F., Munk, W.H., Spindel, R.C., Mercer, J.A., Howe, B.M., Metzger, K., Jr., et al. 2009. A decade of acoustic thermometry in the North Pacific Ocean. Journal of Geophysical Research 114, C07021.

http://dx.doi.org/10.1029/2008JC005124
Dushaw, B.D., Au, W., Beszczynska-Möller, A., Brainard, R., Cornuelle, B.D., Duda, T., Dzieciuch, M., et al. 2010. A global ocean acoustic observing network. In: Hall, J., Harrison, D.E., and Stammer, D., eds. Proceedings of the "Ocean Obs'09: Sustained Ocean Observations and Information for Society, 21-25 September 2009, Venice, Italy. ESA Publication WPP306. Vol. 2:279-291.

Ellis-Evans, C., Holmén, K., Huber, R., Vitale, V., and Ørbæk, J.B. 2013. The Svalbard Integrated Earth Observing System: A regional initiative to build observing capacity for an Arctic observing system. White paper presented at Arctic Observing Summit, 29 April-2 May 2013, Vancouver, British Columbia. Ellison, W.T., Southall, B.L., Clark, C.W., and Frankel, A.S. 2012. A new context-based approach to assess marine mammal behavioral responses to anthropogenic sounds. Conservation Biology 26(1):21 - 28 . http://dx.doi.org/10.1111/j.1523-1739.2011.01803.x

EU Marine Strategy Framework Directive. 2008. Directive 2008/56/EC of the European Parliament and of the Council of 17 June 2008 establishing a framework for community action in the field of marine environmental policy (Marine Strategy Framework Directive). Official Journal of the European Union L 164:19-40.

http://eur-lex.europa.eu/legal-content/EN/TXT/?uri= CELEX:32008L0056

Fahrbach, E., Meincke, J., Østerhus, S., Rohardt, G., Schauer, U., Tverberg, V., and Verduin, J. 2001. Direct measurements of volume transports through Fram Strait. Polar Research 20(2):217-224.

http://dx.doi.org/10.1111/j.1751-8369.2001.tb00059.x

Fer, I. 2009. Weak vertical diffusion allows maintenance of cold halocline in the central Arctic. Atmospheric and Oceanic Science Letters 2(3):148-152.

http://www.iapjournals.ac.cn/aosl/EN/abstract/abstract62. shtml

Fischer, A.S., Hall, J., Harrison, D.E., Stammer, D., and Benveniste, J. 2010. Conference Summary-Ocean information for society: Sustaining the benefits, realizing the potential. In: Hall, J., Harrison, D.E., and Stammer, D., eds. Proceedings of the Ocean Obs'09: Sustained Ocean Observations and Information for Society, 21-25 September 2009, Venice, Italy. ESA Publication WPP-306.

http://dx.doi.org/10.5270/OceanObs09.Summary

Frankel, A.S., and Clark, C.W. 1998. Results of low-frequency playback of M-sequence noise to humpback whales, Megaptera novaeangliae, in Hawaii. Canadian Journal of Zoology 76(3):521-535.

http://dx.doi.org/10.1139/z97-223

Freitag, L., Koski, P., Morozov, A., Singh, S., and Partan, J. 2012. Acoustic communications and navigation under Arctic ice. Proceedings of the MTS/IEEE Oceans 2012, 14-19 October 2012, Hampton Roads, Virginia. http://dx.doi.org/10.1109/OCEANS.2012.6405005

Gascard, J.C. 2011. Steps toward an integrated Arctic Ocean observational system. Oceanography 24(3):174-175.

http://dx.doi.org/10.5670/oceanog.2011.69 
Gavrilov, A.N., and Li, B. 2007. Antarctica as one of the major sources of noise in the ocean. Proceedings of the 2nd International Conference on Underwater Acoustic Measurements: Technologies and Results, 25-29 June 2007, Heraklion, Greece. 1179-1184.

Gavrilov, A.N., and Mikhalevsky, P.N. 2002. Recent results of the ACOUS (Arctic Climate Observation using Underwater Sound) Program. Acta Acoustica 88:783-791.

- 2006. Low-frequency acoustic propagation loss in the Arctic Ocean: Results of the Arctic climate observations using underwater sound experiment. Journal of the Acoustical Society of America 119:3694-3706. http://dx.doi.org/10.1121/1.2195255

Global Ocean Observing System Steering Committee. 2000. Report from the Ocean Observations Panel for Climate, Paris, France.

http://www.wmo.int/pages/prog/gcos/Publications/gcos-69.pdf

Haugan, P.M., Sagen, H., and Sandven, S. 2012. Ocean observatories for understanding and monitoring Arctic change. Proceedings of the MTS/IEEE Oceans 2012, 21-24 May 2012, Yeosu, Korea.

http://dx.doi.org/10.1109/OCEANS-Yeosu.2012.6263520

Huntington, H.P. 2009. A preliminary assessment of threats to Arctic marine mammals and their conservation in the coming decades. Marine Policy 33(1):77-82.

http://dx.doi.org/10.1016/j.marpol.2008.04.003

IOC (Intergovernmental Oceanographic Commission of UNESCO). 2000. OceanObs99 conference statement. IOC/ INF-1137 Paris, France. http://unesdoc.unesco.org/images/0012/001205/120594eo.pdf

ITU/WMO/UNESCO IOC Joint Task Force. 2012. Joint Task Force to investigate the use of submarine telecommunications cables for ocean and climate monitoring and disaster warning. http://www.itu.int/en/ITU-T/climatechange/task-force-sc/ Pages/default.aspx

Johannessen, O.M., Sagen, H., Sandven, S., and Stark, K.V. 2003. Hotspots in ambient noise caused by ice-edge eddies in the Greenland and Barents Seas. IEEE Journal of Ocean Engineering 28(2):212-228.

http://dx.doi.org/10.1109/JOE.2003.812497

Klatt, O., Boebel, O., and Fahrbach, E. 2007. A profiling float's sense of ice. Journal of Atmospheric and Oceanic Technology 24(7):1301-1308. http://dx.doi.org/10.1175/JTECH2026.1

Klinck, H., Nieukirk, S.L., Mellinger, D.K., Klinck, K., Matsumoto, H., and Dziak, R.P. 2012. Seasonal presence of cetaceans and ambient noise levels in polar waters of the North Atlantic. Journal of the Acoustical Society of America 132(3):EL176-181. http://dx.doi.org/10.1121/1.4740226

Küsel, E.T., Mellinger, D.K., Thomas, L., Marques, T.A., Moretti, D., and Ward, J. 2011. Cetacean population density estimation from single fixed sensors using passive acoustics. Journal of the Acoustical Society of America 129:3610-3622.

http://dx.doi.org/10.1121/1.3583504
Kwok, R., and Rothrock, D.A. 2009. Decline in Arctic sea ice thickness from submarine and ICESat records: 1958-2008. Geophysical Research Letters 36, L15501. http://dx.doi.org/10.1029/2009GL039035

Kyhn, L.A., Tougaard, J., Thomas, L., Duve, L.R., Stenback, J., Amundin, M., Desportes, G., and Teilmann, J. 2012. From echolocation clicks to animal density-Acoustic sampling of harbor porpoises with static dataloggers. Journal of the Acoustical Society of America 131:550-560. http://dx.doi.org/10.1121/1.3662070

Lee, C.M., and Gobat, J.I. 2006. Acoustic navigation and communication for High-Latitude Ocean Research Workshop. Eos, Transactions of the American Geophysical Union 87(27):268.

http://dx.doi.org/10.1029/2006EO270004

Marques, T.A., Thomas, L., Ward, J., DiMarzio, N., and Tyack, P.L. 2009. Estimating cetacean population density using fixed passive acoustic sensors: An example with Blainville's beaked whales. Journal of the Acoustical Society of America 125:1982-1994.

http://dx.doi.org/10.1121/1.3089590

Maslanik, J., Stroeve, J., Fowler, C., and Emery, W. 2011. Distribution and trends in Arctic sea ice age through spring 2011. Geophysical Research Letters 38, L13502.

http://dx.doi.org/10.1029/2011GL047735

Mellinger, D.K., Stafford, K.M., Moore, S.E., Dziak, R.P., and Matsumoto, H. 2007. An overview of fixed passive acoustic observation methods for cetaceans. Oceanography 20(4):36-45.

http://dx.doi.org/10.5670/oceanog.2007.03

Mikhalevsky, P.N. 2001. Acoustics, Arctic. In: Steele, J.H., Turekian, K.K., and Thorpe, S.A., eds. Encyclopedia of ocean sciences. Academic Press, Vol. 1. 53-61. http://dx.doi.org/10.1006/rwos.2001.0314

- 2011. Measuring heat in the Arctic Ocean with acoustic thermometry. Proceedings of the 4th International Conference on Underwater Acoustic Measurements: Technologies and Results, 20-24 June 2011, Kos, Greece. 1103-1110.

http://promitheas.iacm.forth.gr/UAM_Proceedings/uam2011/ UAM2011\%20Paper\%2018.1.pdf

Mikhalevsky, P.N., Gavrilov, A.N., and Baggeroer, A.B. 1999. The Transarctic Acoustic Propagation Experiment and climate monitoring in the Arctic. IEEE Journal of Oceanic Engineering 24(2):183-201.

http://dx.doi.org/10.1109/48.757270

Mikhalevsky, P.N., Gavrilov, A.N., Moustafa, M.S., and Sperry, B. 2001. Arctic Ocean warming: Submarine and acoustics measurements. Proceedings of the MTS/IEEE Oceans 2001 Conference, 5-8 November 2001, Honolulu, Hawaii. Vol. 3:1523-1528.

http://dx.doi.org/10.1109/OCEANS.2001.968059

Moore, S.E., and Huntington, H.P. 2008. Arctic marine mammals and climate change: Impacts and resilience. Ecological Applications 18:S157-S165.

http://dx.doi.org/10.1890/06-0571.1 
Moore, S.E., Reeves, R.R., Southall, B.L., Ragen, T.J., Suydam, R.S., and Clark, C.W. 2012a. A new framework for assessing the effects of anthropogenic sound on marine mammals in a rapidly changing Arctic. BioScience 62(3):289-295.

http://dx.doi.org/10.1525/bio.2012.62.3.10

Moore, S.E., Stafford, K.M., Melling, H., Berchok, C., Wiig, Ø., Kovacs, K.M., Lyderson, C., and Richter-Menge, J. 2012 b. Comparing marine mammal acoustic habitats in Atlantic and Pacific sectors of the High Arctic: Year-long records from Fram Strait and the Chukchi Plateau. Polar Biology 35(3):475-480. http://dx.doi.org/10.1007/s00300-011-1086-y

Morawitz, W.M.L., Cornuelle, B.D., and Worcester, P. 1996a. A case study in three-dimensional inverse methods: Combining hydrographic, acoustic, and moored thermistor data in the Greenland Sea. Journal of Atmospheric and Oceanic Technologies 13(3):659-679.

http://dx.doi.org/10.1175/1520-0426(1996)013<0659:ACSITD> 2.0.CO;2

Morawitz, W.M.L., Sutton, P.J., Worcester, P.F., Cornuelle, B.D., Lynch, J.F., and Pawlowicz, R. 1996b. Three-dimensional observations of a deep convective chimney in the Greenland Sea during winter 1988/89. Journal of Physical Oceanography 26(11):2316-2343.

http://dx.doi.org/10.1175/1520-0485(1996)026<2316:TDOOAD $>2.0 . \mathrm{CO} ; 2$

Morozov, A.K., Altshuler, T.W., Jones, C.P., Freitag, L.E., Koski, P.A., and Singh, S. 2011. Underwater acoustic technologies for long-range navigation and communications in the Arctic. Proceedings of the 4th International Conference on Underwater Acoustic Measurements: Technologies and Results, 20-24 June 2011, Kos, Greece. 1119-1126.

http://promitheas.iacm.forth.gr/UAM_Proceedings/uam2011/ UAM2011\%20Paper\%2018.3.pdf

Morozov, A., Jones, C., and Manley, J. 2012. Unmanned vehicles and acoustics for under ice environmental monitoring. Arctic Technology Conference, 3-5 December 2012, Houston, Texas.

Mosca, F., Matte, G., and Shimura, T. 2013. Low-frequency source for very long-range underwater communication. Journal of the Acoustical Society of America 133(1):EL61.

http://dx.doi.org/10.1121/1.4773199

Mouy, X., Hannay, D., Zykov, M., and Martin, B. 2012. Tracking of Pacific walruses in the Chukchi Sea using a single hydrophone. Journal of the Acoustical Society of America 131(2):1349-1358. http://dx.doi.org/10.1121/1.3675008

Munk, W., Worcester, P., and Wunsch, C. 1995. Ocean acoustic tomography. Cambridge Monographs on Mechanics. Cambridge: Cambridge University Press. http://dx.doi.org/10.1017/CBO9780511666926

NRC (National Research Council). 2012. Seasonal-to-decadal predictions of Arctic sea ice: Challenges and strategies. Washington, D.C.: The National Academies Press. http://www.nap.edu/catalog.php?record_id=13515

NSDIC (National Snow \& Ice Data Center). 2012. Arctic sea ice extent settles at record seasonal minimum. Arctic Sea Ice News \& Analysis, Monthly Archives: September 2012. http://nsidc.org/arcticseaicenews/2012/09/
NSF (National Science Foundation) 2013. Ocean observatories initiative (OOI).

http://oceanobservatories.org

Ocean Instruments. 2015. RAFOS float. Woods Hole, Massachusetts: Woods Hole Oceanographic Institution. http://www.whoi.edu/instruments/viewInstrument.do?id=1061

Orcutt, J.A., Vernon, F.L., and Arrott, M. 2013. A cabled Arctic observatory: A practical, long-term approach to open data in the Arctic. White paper presented at Arctic Observing Summit, 29 April - 2 May 2013, Vancouver, British Columbia.

Rainville, L., and Woodgate, R.A. 2009. Observations of internal wave generation in the seasonally ice-free Arctic. Geophysical Research Letters 36, L23604. http://dx.doi.org/10.1029/2009GL041291

Rampal, P., Weiss, J., Dubois, C., and Campin, J.-M. 2011. IPCC climate models do not capture Arctic sea ice drift acceleration: Consequences in terms of projected sea ice thinning and decline. Journal of Geophysical Research 116, C00D07. http://dx.doi.org/10.1029/2011JC007110

Rossby, T., Dorson, D., and Fontaine, J. 1986. The RAFOS System. Journal of Atmospheric and Oceanic Technology 3(4):672-679.

http://dx.doi.org/10.1175/1520-0426(1986)003<0672:TRS $>$ 2.0.CO;2

Sagen, H., Sandven, S., Beszczynska-Möller, A., Boebel, O., Duda, T.F., Freitag L., Gascard J.C., et al. 2010. Acoustic technologies for observing the interior of the Arctic Ocean. In: Hall, J., Harrison, D.E., and Stammer, D., eds. Proceedings of the Ocean Obs'09: Sustained Ocean Observations and Information for Society, 21-25 September 2009, Venice, Italy. ESA Publication WPP-306.

Sagen, H., Sandven, S., Worcester, P., Dzieciuch, M., and Skarsoulis, E. 2008. The Fram Strait acoustic tomography system. Journal of the Acoustical Society of America 123:2991-2995.

http://dx.doi.org/10.1121/1.2932531

Sagen, H., Sandven, S., Worcester, P., Beszczynska-Möller, A., Fahrbach, E., and Morozov, A. 2011. The Fram Strait acoustic system for tomography, navigation and passive listening. Proceedings of the 4th International Conference on Underwater Acoustic Measurements: Technologies and Results, 20-24 June 2011, Kos, Greece.

http://promitheas.iacm.forth.gr/UAM_Proceedings/uam2011/ UAM2011\%20Paper\%2018.2.pdf

Sagen, H., Tollefsen, D., and Tengesdal, H.C. 2014. The soundscape of the Fram Strait marginal ice zone. Proceedings of the 2nd Underwater Acoustic Conference, 22-27 June 2014, Rhodes, Greece. http://dx.doi.org/10.13140/2.1.1923.3928

Sandven, S., Sagen, H., Bertino, L., Beszczynska-Möller, A., Fahrbach, E., Worcester, P.F., Dzieciuch, M.A., et al. 2013. The Fram Strait integrated ocean observing and modelling system. In: Dahlin, H., Flemming, N.C., and Petersson, S.E., eds. Sustainable Operational Oceanography: Proceedings of the Sixth International Conference on EuroGOOS, 4-6 October 2011, Sopot, Poland. 50-58.

http://eurogoos.eu/documents/conference-proceedings/ 
Schofield, O., Glenn, S., Orcutt, J., Arrott, M., Meisinger, M., Gangopadhyay, A., Brown, W., et al. 2010. Automated sensor networks to advance ocean science. Eos, Transactions American Geophysical Union 91(39):345-346. http://dx.doi.org/10.1029/2010EO390001

Shephard, G.E., Müller, R.D., and Seton, M. 2013. The tectonic evolution of the Arctic since the Pangea breakup: Integrating constraints from surface geology and geophysics with mantle structure. Earth-Science Reviews 124:148-183.

http://dx.doi.org/10.1016/j.earscirev.2013.05.012

Skarsoulis, E.K., and Piperakis, G.S. 2009. Use of acoustic navigation signals for simultaneous localization and soundspeed estimation. Journal of the Acoustical Society of America 125(3):1384-1393.

http://dx.doi.org/10.1121/1.3076202

Skarsoulis, E., Piperakis, G., Kalogerakis, M., Sagen, H., Haugen, S.A., Beszczynska-Möller, A., and Worcester, P.F. 2010. Tomographic inversions from the Fram Strait 2008-9 experiment. Proceedings of the European Conference on Underwater Acoustics, 5-9 July 2010, Istanbul, Turkey. $265-271$.

Stafford, K.M., Moore, S.E., Berchok, C.L., Wiig, Ø., Lydersen, C., Hansen, E., Kalmbach, D., and Kovacs, K.M. 2012. Sptisbergen's endangered bowhead whales sing through the polar night. Endangered Species Research 18:95-103. http://dx.doi.org/10.3354/esr00444

Stafford, K.M., Okkonen, S.R., and Clarke, J.T. 2013. Correlation of a strong Alaska coastal current with the presence of beluga whales Delphinapterus leucas near Barrow, Alaska. Marine Ecology Progress Series 474:287-297. http://dx.doi.org/10.3354/meps10076

Tollefsen, D., and Sagen, H. 2014. Seismic exploration noise reduction in the marginal ice zone. Journal of the Acoustical Society of America 136(1):EL47. http://dx.doi.org/10.1121/1.4885547

Van der Graaf, A.J., Ainslie, M.A., André, M., Brensing, K., Dalen, J., Dekeling, R.P.A., Robinson, S., Tasker, M.L., Thomsen, F., and Werner, S. 2012. European Marine Strategy Framework Directive - Good Environmental Status (MSFD GES): Report of the Technical Subgroup on Underwater Noise and Other Forms of Energy.

http://ec.europa.eu/environment/marine/pdf/MSFD_ reportTSG_Noise.pdf
Van Uffelen, L.J., Nosal, E.-M., Howe, B.M., Carter, G.S., Worcester, P.F., Dzieciuch, M.A., Heaney, K.D., Campbell, R.L., and Cross, P.S. 2013. Estimating uncertainty in subsurface glider position using transmissions from fixed acoustic tomography sources. Journal of the Acoustical Society of America 134(4):3260-3271. http://dx.doi.org/10.1121/1.4818841

Wadhams, P. 2012. Arctic ice cover, ice thickness and tipping points. Ambio 41(1):23-33. http://dx.doi.org/10.1007/s13280-011-0222-9

Ward, J.A., Thomas, L., Jarvis, S., DiMarzio, N., Moretti, D., Marques, T.A., Dunn, C., Claridge, D., Hartvig, E., and Tyack, P. 2012. Passive acoustic density estimation of sperm whales in the Tongue of the Ocean, Bahamas. Marine Mammal Science 28:E444-E455. http://dx.doi.org/10.1111/j.1748-7692.2011.00560.x

Webster, S.E., Freitag, L.E., Lee, C.M., and Gobat, J.I. 2015. Towards real-time under-ice acoustic navigation at mesoscale ranges. Proceedings of the IEEE International Conference on Robotics and Automation, 25-30 May 2015, Seattle, Washington.

Worcester, P.F., Lynch, J.F., Morawitz, M.W.L., Pawlowicz, R., Sutton, P.J., Cornuelle, B.D., Johannessen, O.M., et al. 1993. Evolution of the large-scale temperature field in the Greenland Sea during 1988-89 from tomographic measurements. Geophysical Research Letters 20(20):2211-2214.

http://dx.doi.org/10.1029/93GL02373

Worcester, P.F., Carey, S., Dzieciuch, M.A., Green, L.L., Horwitt, D., Lemire, J.C., and Norenberg, M. 2009. Distributed vertical line array (DVLA) acoustic receiver. Proceedings of the 3rd International Conference on Underwater Acoustic Measurements: Technologies and Results, 21-26 June 2009, Nafplion, Greece. 113-118.

http://promitheas.iacm.forth.gr/UAM_Proceedings/ uam2009/3-4.pdf

Worcester, P.F., Dzieciuch, M.A., Mercer, J.A., Andrew, R.K., Dushaw, B.D., Baggeroer, A.B., Heaney, K.D., et al. 2013. The North Pacific Acoustic Laboratory deep-water acoustic propagation experiments in the Philippine Sea. Journal of the Acoustical Society of America 134:3359-3375.

http://dx.doi.org/10.1121/1.4818887 